\title{
NILAI-NILAI DAKWAH; AKTIVITAS IBADAH DAN PERILAKU SOSIAL
}

\author{
Umi Hayati \\ Guru PAI SDN Blendung Pemalang \\ umihayati@gmail.com
}

\begin{abstract}
Preaching creates behavior of Muslims in practising Islam as the religion of rahmatan lil'alamin that should be spread to all mankind. The activity of worship is closely related to social behavior of students. Presumably, the intensive activity of worship is in line with rigorous social behavior. The activity of worship actually indicates the level of faith and devotion to God, so it will create humans with noble characters in individual and social life. The sample indicators are the offers of the main and additional prayers. If prayers are performed actively, they will bring positive attitudes to stay away from shamful and dishonor acts. It means that prayers will lead humans to have noble behaviours and social interaction.
\end{abstract}

Keywords: Preaching, prayers, social behaviour

\begin{abstract}
Abstrak
Dakwah menjadikan perilaku Muslim dalam menjalankan Islam sebagai agama rahmatan lil'alamin yang harus didakwahkan kepada seluruh manusia. Aktivitas ibadah sangat erat hubungannya dengan perilaku sosial para siswa, dengan kesimpulan bahwa aktivitas ibadah yang tinggi maka perilaku sosial juga tinggi. Ini semua karena aktivitas ibadah menunjukkan tingkat keimanan dan ketaqwaan pada Allah sehingga tercipta manusia yang berakhlak mulia dalam kehidupan individu maupun bermasyarakat. Contohnya pada indikator mengerjakan salat wajib dan sunah. Ibadah salat jika dilakukan dengan aktif akan mampu melahirkan sikap positif yaitu menjauhi perbuatan yang keji dan mungkar. Ini ada kaitanya, apabila ibadah salat dikerjakan dengan aktif maka seseorang akan berperilaku baik dalam interaksi sosial
\end{abstract}

Kata Kunci: Dakwah, ibadah, perilaku sosial 
INJECT: Interdisciplinary Journal of Communication, Vol.2, No.2, Des. 2017: h. 175-192

\section{Pendahuluan}

Dakwah tidak akan berhasil apabila seorang dai tidak menyerahkan dirinya secara totalitas untuk berjuang di jalan Allah. Dakwah yang berhasil ialah dakwah yang efektif membimbing manusia untuk amar ma'ruf dan nahi mungkar. Dai harus mampu menjiwai dan menjadikannya sebagai pedoman dalam hidupnya agar dapat dijadikan alat pengontrol bagi perbuatan-perbuatannya, pemkiran dan sikap mentalnya. Sehingga anak didik nanti diharapkan mendapat petunjuk untuk mendekatkan diri kepada Allah yaitu dengan ibadah.

Ibadah sebagai bentuk penyembahan seorang hamba terhadap Tuhannya yang dilakukan dengan merendahkan diri serendah-rendahnya, dengan hati yang ikhlas menurut cara-cara yang ditentukan oleh agama (Suyono, 1998:11). Dengan demikian ibadah merupakan unsur mutlak dalam agama. Pelaksanaan ibadah dalam Islam tidak boleh sampai mengabaikan kewajiban yang berhubungan dengan kebutuhan duniawi. Manusia perlu bekerja untuk mencukupi kebutuhan hidupnya serta kebutuhan untuk berinteraksi dan bekerja sama dengan sesamanya, karena manusia tidak dapat hidup tanpa bantuan orang lain.

Manusia bukan saja merupakan makhluk sosial, yaitu makhluk yang harus hidup dengan sesamanya dan selalu membutuhkan kerjasama dengan sesamanya, tetapi lebih dari itu manusia harus bisa menyesuaikan diri dengan situasi yang ada di sekitarnya. Seorang muslim yang menyadari ajaran-ajaran agamanya akan menjadi pribadi yang berjiwa sosial dan akan bergaul dalam kehidupan sosial dengan cara yang terbaik sesuai dengan pemahamannya atas agama yang benar serta nilai-nilai kemanusiaan yang mulia dan dianjurkan dalam bidang interaksi sosial. Hadirnya arus globalisai sebagai akibat perkembangan ilmu pengetahuan dan teknologi telah menimbulkan berbagai dampak. Hal ini disebabkan oleh perkembangan teknologi yang semakin lama semakin meningkat, namun tidak diimbangi dengan pemberian bekal keagamaan yang cukup, 
sehingga remaja mudah terpengaruh untuk meniru apa yang dilihatnya.

Pada masa anak-dewasa, kontak sosial remaja dengan orang lain semakin meningkat dan semakin luas remaja menemui bahwa apa yang benar dalam keluarga belum tentu benar di lingkungan sekolah. Hal ini dapat menimbulkan perilaku-perilaku remaja yang tidak baik, bahkan bertentangan dengan norma-norma yang berlaku, baik itu norma agama, norma susila maupun norma sosial. Diantara nilai dan norma yang bisa membatasi dan mengarahkan perilaku para remaja bisa diperoleh dari bahan pelajaran sekolah, baik dalam bidang studi PPKN (berisi tentang moral) maupun bidang studi agama (berisi anjuran dan larangan) serta kegiatan-kegiatan keagamaan lainnya yang dapat dijadikan pedoman dalam pengendalian gejolak dorongan dalam dirinya.

Dewasa ini makin terasa perlunya remaja dibentengi dengan nilai-nilai luhur agama, mengingat pengaruhnya yang besar terhadap kehidupan remaja, tanpa nilai-nilai luhur agama remaja dapat melakukan kelalaian, kealpaan, bahkan sampai lupa diri. Ada berbagai komponen yang memengaruhi terjadinya perilaku sosial siswa di sekolah, yaitu lingkungan keluarga, lingkungan sekolah, lingkungan masyarakat dan potensi remaja itu sendiri. Begitu banyak cara dan upaya yang ditempuh oleh masyarakat lewat pemuka agama dan oleh lembaga pendidikan lewat guru bimbingan dan penyuluhan untuk mengantisipasi meningkatnya perilaku menyimpang. Baik dilingkungan masyarakat maupun lingkungan pendidikan, selain teori tentang pemahaman moral juga diberlakukannya suatu kegiatan yang sering disebut aktivitas ibadah.

\section{Nilai-nilai Dakwah}

Dakwah menurut etimologi (bahasa) berasal dari kata bahasa Arab: da'a-yad'u-da'watan yang berarti mengajak, menyeru, dan memanggil (Amin, 2008:3). Di antara makna dakwah secara bahasa adalah an-Nida artinya memanggil; da'a filanun ika fulanah, artinya si fulan mengundang 
fulanah. Menyeru, ad-du'a ila syai'i, artinya menyeru dan mendorong pada sesuatu (Aziz, 2011:1). Dalam dunia dakwah, orang yang berdakwah biasa disebut $d a^{\prime} i$ dan orang yang menerima dakwah atau orang yang didakwahi disebut dengan mad'u (Saputra, 2011:1).

Dalam pengertian istilah dakwah diartikan sebagai berikut: (1) Toha Yahya Oemar menyatakan bahwa dakwah Islam sebagai upaya mengajak umat dengan cara bijaksana kepada jalan yang benar sesuai dengan perintah Tuhan untuk kemaslahatan di dunia dan akhirat. Sedangkan Hamka (dalam Saputra, 2011:1) menjelaskan, dakwah adalah seruan panggilan untuk menganut suatu pendirian yang ada dasarnya berkonotasi positif dengan substansi terletak pada aktivitas yang memerintahkan amar ma'ruf nahi mungkar.

Dari beberapa definisi di atas secara singkat dapat disimpulkan bahwa dakwah merupakan suatu aktivitas yang dilakukan oleh informan (da'i) untuk menyampaikan informasi kepada pendengar (mad'u) mengenai kebaikan dan mencegah keburukan. Aktivitas tersebut dapat dilakukan dengan menyeru, mengajak atau kegiatan persuasif lainnya. Dakwah menjadikan perilaku Muslim dalam menjalankan Islam sebagai agama rahmatan lil'alamin yang harus didakwahkan kepada seluruh manusia, yang dalam prosesnya melibatkan unsur: $D a^{\prime} i$ (subyek), maaddah (materi), thoriqoh (metode), wasilah (media), dan mad'u (objek) dalam mencapai maqashid (tujuan) dakwah yang melekat dengan tujuan Islam yaitu mencapai kebahagiaan hidup di dunia dan akhirat (Saputra, 2011:1).

Islam sebagai agama merupakan penerus dari risalah-risalah yang dibawa nabi terdahulu, terutama agama-agama samawi seperti Yahudi dan Nasrani. Islam diturunkan karena terjadinya distorsi ajaran agama, baik karena hilangnya sumber ajaran agama sebelumnya ataupun pengubahan yang dilakukan pengikutnya. Dalam agama Nasrani misalnya, hingga saat ini belum ditemukan kitab suci yang asli. 
Karena dakwah merupakan aktivitas amar ma'ruf nahi mungkar, dakwah tidak selalu berkisar pada permasalahan agama seperti pengajian atau kegiatan yang dianggap sebagai kegiatan keagamaan lainnya. Paling tidak ada tiga pola yang dapat dipahami mengenai dakwah. Dakwah sebagaibentuk komunikasi, karena komunikasiadalah kegiatan informatif, yakni agar orang lain mengerti, mengetahui dan kegiatan persuasif, yaitu agar orang lain bersedia menerima suatu paham atau keyakinan, melakukan suatu paham atau keyakinan, melakukan suatu kegiatan atau perbuatan dan lain-lain. Keduanya (dakwah dan komunikasi) merupakan bagian integral yang tidak dapat dipisahkan.

Dakwah disebut komunikasi, akan tetapi komunikasi belum tentu dakwah, adapun yang membedakannya adalah terletak pada isi dan orientasi pada kegiatan dakwah dan kegiatan komunikasi. Pada komunikasi isi pesannya umum bisa juga berupa ajaran agama, sementara orientasi pesannya adalah pada pencapaian tujuan dari komunikasi itu sendiri, yaitu munculnya efek dan hasil yang berupa perubahan pada sasaran. Sedangkan pada dakwah isi pesannya jelas berupa ajaran Islam dan orientasinya adalah penggunaan metode yang benar menurut ukuran Islam. Dakwah merupakan komunikasi ajaran-ajaran Islam dari seorang $d a^{\prime} i$ kepada umat manusia dikarenakan didalamnya terjadi proses komunikasi.

Dakwah merupakan suatu proses motifasi agar manusia melakukan kebaikan dan melarang manusia berbuat kemungkaran, agar mereka mendapat kebahagiaan dunia dan akhirat masyarakat Makkah memelihara kedudukan tata nilai yang tinggi dan istimewa, karena hal semacam itu memberikan kehidupan yang makmur. Kaum Quraisy memandang diri mereka lebih mulia dari bangsa arab. Jika kaum Quraisy tunduk kepada Nabi Muhammad saw, itu sama artinya menyerahkan semua kekuasaan kepada keluarga Nabi Muhammad saw. Mereka tidak akan membedakan antara kenabian dan kekuasaan. 
INJECT: Interdisciplinary Journal of Communication, Vol.2, No.2, Des. 2017: h. 175-192

\section{Aktivitas Ibadah}

Dalam rangka membentuk manusia seutuhnya, sehat jasmani dan rohani maka disamping memahami pengetahuan juga harus mengamalkan pengetahuan tersebut. Pengetahuan-pengetahuan yang telah diketahui harus diamalkan dalam kehidupan sehari-hari. Seperti halnya pengetahuan agama, maka segala perbuatannya harus berdasarkan pengetahuan agama. Agama Islam mengajarkan pengetahuan yang dapat menjadi pedoman hidup serta mengatur kehidupan baik secara individu maupun kelompok agar tercipta kehidupan yang harmonis. Dalam mengamalkan agama Islam memerlukan kegiatan-kegiatan keagamaan atau aktivitas-aktivitas keagamaan yang berbentuk ibadah. Kegiatan ibadah adalah kesibukan yang berkaitan dengan masalah ibadah, artinya kesibukan atau kegiatan tersebut berupa perbuatan yang ditujukan untuk memperoleh ridha Allah. Kebiasaan-kebiasaan dan aktivitas ibadah yang ditanamkan sejak kecil sangat memengaruhi perkembangan keagamaan anak.

\section{Dasar dan Tujuan Aktivitas Ibadah}

Allah menetapkan perintah ibadah sebenarnya merupakan suatu keutamaan yang besar kepada makhluknya, karena apabila direnungkan, hakikat perintah beribadah itu berupa peringatan agar kita menunaikan kewajiban terhadap Allah yang telah melimpahkan karunia-Nya (Triyanto, 1998:4). Dalam hal aktivitas ibadah, Allah berfirman: Artinya: "Hai manusia, sembahlah Tuhanmu yang telah menciptakanmu dan orangorang yang sebelummu, agar kamu bertakwa"(QS.al Baqarah:21).

Aktivitas ibadah bersumber dari al-Quran dan Hadis sehingga dapat terarah pada jalan menuju ridho Allah. Mengenai tujuan aktivitas ibadah al-Syaibani menjabarkan sebagai berikut:(1) Tujuan yang berkaitan dengan individu, mencakup perubahan yang berupa pengetahuan, tingkah laku, jasmani dan rohani, serta kemampuan-kemampuan yang harus dimiliki untuk hidup di dunia dan di akhirat. (2) Tujuan yang berkaitan dengan 
masyarakat, mencakup tingkah laku masyarakat, tingkah laku individu dalam masyarakat, perubahan kehidupan masyarakat, memperkaya pengalaman masyarakat. (3) Tujuan profesional yang berkaitan dengan pendidikan dan pengajaran sebagai ilmu, sebagai seni, sebagai profesi, dan sebagai kegiatan masyarakat (Tafsir, 2008:49). Dari pendapat di atas dapat disimpulkan bahwa tujuan kegiatan ibadah adalah terbentuknya karakter, sifat dan tingkah laku yang baik dalam peranannya sebagai makhluk yang berhubungan dengan makhluk lainnya maupun hubungannya dengan sang khaliq yaitu Allah SWT.

\section{Macam-macam Aktivitas Ibadah}

Dalam aktivitas ibadah setidaknya ada enam macam yaitu ibadah sholat, puasa, zakat dan shodaqoh, berdoa dan membaca al-Quran, yang masing-masing ada syarat tertentu yang dilakukan. Secara detail (1) Sholat yaitu secara bahasa salat berarti doa, sedangkan menurut syara artinya bentuk ibadah yang terdiri atas perkataan dan perbuatan yang dimulai dengan takbir dan diakhiri dengan salam (Suyono, 1998:61). Salat merupakan ibadah, maka setiap muslim yang mengakui dirinya seorang Islam, ia di wajibkan melaksanakannya sejak baligh. Kewajiban mendirikan salat diterangkan dalam al-Quran surat An-Nisa ayat 103: yang artinya "apabila kamu telah menyelesaikan shalat(mu), ingatlah Allah di waktu berdiri, di waktu duduk dan di waktu berbaring. Kemudian apabila kamu Telah merasa aman, Maka Dirikanlah shalat itu (sebagaimana biasa). Sesungguhnya shalat itu adalah fardhu yang ditentukan waktunya atas orangorang yang beriman. Bila salat dikerjakan secara rutin dan tepat pada waktunya, maka akan terhindar dari bermacam-macam godaan dan tidak akan berani melanggar syariat agama karena salat merupakan ibadah yang dapat mencegah perbuatan keji dan mungkar. Jika seseorang terbiasa melakukan salat dengan baik dan teratur, maka dalam diri seseorang tersebut akan tertanam akhlak yang baik. (2) Puasa, yaitu menahan diri dari makan, minum, dan berhubungan seks, sejak terbitnya fajar 
hingga tenggelamnya matahari, dengan (mengharap) perhitungan Allah, mempersiapkan diri untuk bertakwa, dengan mendekatkan diri kepada Allah dan mendidik kehendak (Triyanto, 2002:67-68). Puasa Ramadhan merupakan ibadah pokok dan merupakan rukun islam yang ke empat. Hukumnya fardhu ain atas setiap muslim yang sudah baligh. Kewajiban ini sebagaimana firman Allah dalam surat al-Baqarah ayat 183. Artinya: "Hai orang-orang yang beriman, diwajibkan atas kamu berpuasa sebagaimana diwajibkan atas orang-orang sebelum kamu agar kamu bertaqwa. Berdasarkan ayat tersebut, maka puasa ramadhan adalah kewajiban yang tidak boleh di tinggalkan jika tanpa sebab, baik bagi orang tua maupun anak yang sudah baligh. Pada hakikatnya puasa merupakan pendidikan dan latihan kejiwaan agar manusia mampu mengendalikan diri serta mengarahkan keinginan-keinginan. Pengendalian dan pengarahan ini sangat dibutuhkan oleh manusia, baik pribadi maupun kelompok, karena secara umum jiwa manusia sangat mudah terpengaruh oleh berbagai hal, terutama bagi mereka yang tdak memiliki kesadaran untuk mengendalikan diri serta tekad yang kuat untuk melawan bisikan atau bujukan negatif (Triyanto, 1998:68). (3) Zakat dan Shadaqoh, yaitu harta tertentu yang wajib dikeluarkan seseorang untuk fakir miskin dan sesuai dengan perintah syara (Suyono, 1998:191). Zakat merupakan kewajiban agama yang wajib dilaksanakan, karena dengan zakat tersebut dapat meningkatkan kesejahteraan masyarakat serta mencegah adanya perbedaan yang mencolok antara golongan kaya dan miskin. Seseorang yang mengeluarkan zakat akan memperoleh pahala ganda. Salah satu dari dua pahala yang akan diperolehnya adalah menyucikan diri dari sifat bakhil, disamping memperkuat kecintaan kepada Allah swt. Inilah kualitas-kualitas yang tumbuh semakin kuat didalam hati, yang mendorong manusia untuk selalu rindu berjumpa (bertemu) dengan Allah swt. Pahala kedua adalah keutamaan yang didapatkan dari doa mereka yang menerima zakat atau sedekah, karena hati orang yang baik akan selalu berbekas, baik kini atau dimasa nanti (Ghazali, 2001:75). (4) Berdoa, yaitu suatu tugas 
agama yang sangat penting kedudukannya dan sangat mahal nilainya. Doa merupakan salah satu pintu yang besar diantara pintu-pintu ibadah yang lain, dalam menghambakan diri kepada Allah dan memperlihatkan ketundukan jiwa kepada-Nya. Doa merupakan permohonan kepada Allah dengan harapan semoga Allah mengabulkan cita-cita bagi dirinya, baik di dunia maupun di akhirat. Berdoa sangat penting bagi manusia, karena dengan doa yang sungguh-sungguh minta kepada Allah dapat menjadikan iman dan taqwa seseorang bertambah. Selain itu doa juga bisa menjadi penerangan rohani. Kegelapan hidup rohani tidak bisa diterangi secara duniawi. Usaha untuk mendapatkan penerangan rohani dengan cara duniawi, baik melalui dunia hiburan, lezatnya makanan, lengkapnya fasilitas hidup, dan sebagainya tidak akan menyelesaikan masalah rohani. Hanya doa yang bisa menjadi sarana untuk memohon penerangan rohani.tidak semua kondisi akan menjadi langsung berubah karena doa, tetapi orang yang berdoa diberi penerangan rohani secara langsung untuk menghadapi berbagai kondisi (Marsudi, 2007:48). Doa, di samping sebagai bentuk amal ibadah, juga merupakan karunia Allah yang sangat berharga, karena melalui doa, Allah akan memberikan sesuatu yang dipandang baik dan bermanfaat bagi hamba-Nya. Berdoa hendaknya dilakukan dengan ikhlas dan sungguh-sungguh agar segera dikabulkan oleh Allah. (5) Membaca al-Quran, di samping rajin berdoa seorang muslim di wajibkan membaca al-Quran. Al-Quran adalah kalam Allah yang tiada tandingannya (mukjizat), diturunkan kepada Nabi Muhammad saw, penutup para Nabi dan Rasul, dengan perantaraan Malaikat Jibril as ditulis dalam mushaf-mushaf yang disampaikan kepada kita dengan jalan mutawatir (oleh orang banyak), serta mempelajarinya merupakan ibadah, dimulai dengan surat al-Fatihah dan diakhiri dengan an-Naas (Musbikin, 2007:221). Membaca al-Quran selain beribadah juga sebagai alat penawar hati bagi yang jiwanya sedang gelisah.Allah menurunkan al-Quran untuk umat manusia agar mereka dapat membedakan antara yang haq dan yang batil dan agar menjadi pelita yang selalu menerangi jalan-jalan yang 
dilaluinya, hingga mereka dapat keluar dari kegelapan menuju cahaya dan kehidupan yang membahagiakan (Imarah, 2008:158). Di samping itu al-Quran juga merupakan pedoman hidup bagi umat manusia, karena di dalamnya berisi tentang petunjuk bagi umat aislam. Mengingat pentingnya al-Quran itu, maka kita diwajibkan untuk mempelajari dan mengamalkan setiap hari.

\section{Faktor-faktor yang Memengaruhi Aktivitas Ibadah}

Faktor yang memengaruhi aktivitas belajar diantaranya adalah: (1) Lingkungan Keluarga, di lingkungan keluarga seorang anak pertama kali mengenal pendidikan dan perkembangan kepribadiannya. Untuk mengembangkan kepribadian itu hendaklah orang tua dapat menciptakan situasi keluarga yang bernafaskan agama. Apabila dalam kehidupan sehari-hari anak selalu berhadapan dengan kebiasaan-kebiasaan beragama yang baik, maka kebiasaan itu akan melekat pada diri anak, karena pada dasarnya semenjak lahir fitrah agama itu telah ada. Bahkan lebih jauh, dapat dikatakan bahwa kepercayaannya kepada Tuhan atau keyakinan beragamanya akan sangat dipengaruhi oleh suasana hubungan dalam keluarga waktu kecil itu (Daradjat, 1976:19). (2) Lingkungan pendidikan, adalah lembaga pendidikan yang sangat penting sesudah keluarga. Pada waktu anak menginjak umur 6 atau 7 tahun perkembangan intelektual daya pikir telah meningkat sedemikian rupa, Pada saat ini anak telah cukup matang belajar di sekolah dan memang sekolah telah di atur sedemikian rupa dan mampu melaksanakan tugas-tugas pendidikan. Sikap seorang guru, kepribadiannya, cara bergaul dengan sesama guru, dengan keluarga dan masyarakat merupakan figur bagi anak. Dengan demikian apabila kondisi sekolah memberikan angin segar bagi anak dengan kebiasaan yang baik maka akan membawa pengaruh yang baik bagi pembinaan aktivitas ibadah anak. (3) Lingkungan masyarakat, sebagai makhluk hidup kita tidak bisa terlepas dari masyarakat. Semakin kita dekat dengan masyarakat maka semakin dalam pengaruhnya, apabila 
perilaku pada masyarakat tersebut menuju pada norma-norma yang ada (kebaikan) maka anak-anak akan mengikuti langkah-langkah mereka, begitu pula sebaliknya apabila kondisi pada masyarakat tidak mendukung terbentuknya perilaku anak sesuai norma kebaikan, maka anakpun akan mengikuti langkah mereka. Masyarakat mempunyai pengaruh besar dalam memberikan arah terhadap pendidikan anak, terutama para pemimpin masyarakat atau penguasa yang ada didalamnya. (4) Lingkungan keagamaan, baik lembaga-lembaga pendidikan keagamaan, rumah-rumah ibadah (mushalla dan masjid) maupun kegiatan-kegiatan keagamaan seperti pengajian, pertemuan-pertemuan keagamaan sangat penting peranannya dalam pembinaan aktifitas ibadah anak. Karena pengalaman yang dilihat melalui penglihatan dan pendengaran tentang rumah ibadah dan kegiatan yang dilakukan akan membuat hati anak selalu dekat dengan agama dan dengan sendirinya sikapnya terhadap agama menjadi positif. Anak akan berperilaku baik, memiliki rasa percaya dan takut kepada Allah, serta dalam melaksanakan segala sesuatu disesuaikan dengan ajaran-ajaran agama yang dianutnya. Kebiasaan-kebiasaan yang baik itu perlu ditanamkan sejak dini mulai dari keluarga sampai pada masyarakat, di mana hal tersebut diharapkan dapat membawa pengaruh yang positif bagi aktivitas ibadah anak.

\section{Perilaku Sosial}

Perilaku adalah tanggapan atau reaksi individu terhadap rangsangan atau lingkungan (Salimi, 1994:198). Sosial adalah berkenaan dapat diartikan bahwa perilaku sosial adalah sebuah reaksi dari individu terhadap ransangan yang timbul dari pengalaman atau dorongan dari masyarakat.

Perilaku sering juga disebut dengan akhlak. Seperti yang telah kita ketahui bahwa akhlak atau moral membutuhkan bimbingan agar terarah pada akhlak yang baik dan bukan pada akhlak yang buruk atau 
INJECT: Interdisciplinary Journal of Communication, Vol.2, No.2, Des. 2017: h. 175-192

menyimpang. Dalam proses pembinaan akhlak atau moral sebaiknya sesuai dengan nilai dan norma agama. Seperti dalam tulisan Zakiyah Daradjat(1975:860), "Supaya agama dapat menjadi pengendali moral bagi seseorang, hendaknya agama itu masuk dalam pembinaan kepribadiannya dan merupakan unsur yang tidak dapat dipisahkan dalam integritas kepribadian itu".

Nilai dan norma yang berasal dari agama tidak akan pernah berubah karena semua bersumber pada al-Quran dan as-Sunnah. Manusia sebagai makhluk sosial hidup diantara masyarakat yang mempunyai serangkaian aturan kehidupan. Norma yang ada dalam masyarakat baik yang bersumber dari agama ataupun dari adat istiadat setempat merupakan tolok ukur yang dipakai masyarakat untuk mengukur perilaku seseorang, baik itu perilaku baik maupun perilaku buruk. Seseorang akan dianggap berperilaku buruk atau meyimpang ketika perbuatan dan tingkah lakunya tidak sesuai dan melanggar norma yang ada.

Sekarang ini zaman sudah berubah, seseorang akan mudah melakukan pelanggaran terhadap norma yang ada. Bentuk-bentuk pelanggaran terhadap norma itulah wujud dari kemerosotan moral dan akhlak. Ada beberapa faktor yang menyebabakan terjadinya kemersotan moral pada anak. Faktor-faktor tersebut antara lain sebagai berikut: (1) Kurang tertanamnya jiwa agama. Jiwa agama yang tertanam kuat dalam diri seseorang akan menjadi benteng moral yang sangat tangguh. Seseorang yang benar-benar memahami ajaran agama Islam dengan baik akan selalu berusaha melakukan kebaikan dan menghindari serta menjauhi perilaku yang menyimpang. Sebaliknya seseorang yang jauh dari agama akan semakin sulit memelihara moral dan akan semakin mudah melakukan pelanggaran-pelanggaran. (2) Pendidikan moral tidak terlaksana dengan baik. Pembinaan moral sebaiknya dilaksanakan sejak dini. Anak-anak belum mengetahui tentang batasanan dan ketentuan moral, oleh sebab itu para orang tua sebaiknya memberikan pendidikan moral yang baik 
agar anak tumbuh dengan kebiasaan-kebiasaan yang baik pula. (3) Suasana atau kondisi keluarga yang kurang baik. Suasana dalam keluarga sangat memengaruhi pola pikir dan perilaku anak. Keadaan yang menyenangkan dalam keluarga akan membuat anak merasa nyaman, tetapi sebaliknya keadaan keluarga yang kurang baik akan membuat anak merasa tidak nyaman, cemas, gelisah dan ketakutan sehingga mendorong anak melampiaskan perasaannya pada hal-hal yang salah. (4) Adanya pengaruh budaya asing. Inilah faktor yang sangat dominan dalam masalah kemerosotan akhlak atau moral. Budaya asing yang tidak sesuai dengan norma agama dan norma bangsa dapat mengubah pribadi mayarakat terutama remaja. (5) Keadaan lingkungan masyarakat sekitar. Lingkngan sekitar sangat memengaruhi pribadi dan perilaku seseorang. Jika lingkungan baik maka individu yang berada di situ juga akan baik. Demikian juga sebaliknya, jika lingkungan buruk maka individu tersebut juga akan terbawa oleh pengaruh buruk lingkungan tersebut. (6) Minimnya kegiatan untuk mengisi waktu luang. Seseorang harus memahami betapa pentingnya waktu dalam kehidupan (Muthowi', 2000:3). Kurangnya kegiatan untuk mengisi waktu luang akan memberikan peluang kepada seseorng untuk melakuakan hal-hal yang negatif. Oleh karena itu sebaiknya seseorang diberikan bimbingan dan pengarahan untuk mengisi waktu luang dengan kegiatan-kegiatan yang positif.

Begitu banyak faktor yang menyebabkan kemerosotan moral dan akhlak. Karena itulah perlu ditanamkan nilai-nilai agama dan pembinaan moral agar tidak terjadi perilaku yang menyimpang. Moral yang baik tidak akan terbentuk tanpa adanya pembiasaan dan teladan yang baik. Oleh karena itu, pendidikan moral yang diajarkan kepada anak-anak sebaiknya tidak berhenti pada proses pengajaran saja. Menurut Kohlberg (1995:65), anak-anak tidak hanya perlu diajar hal-hal moral, mereka perlu diajar untuk mempraktikkan perilaku dan kebiasaan moral, serta perlu diberi ganjaran atas perilaku moralnya atau dihukum karena mengikuti godaan. 
Langkah tersebut dilakukan agar anak tidak hanya mengetahui ajaran tentang moral saja tetapi juga mampu melaksanakan dalam kehidupan sehari-harinya. Perilaku sosial terdiri dari dua macam yaitu perilaku sosial yang negatif dan perilaku sosial yang positif. Perilaku sosial yang negatif terdiri dari perilaku yang menyimpang yang tidak sesuai dengan aturan dan norma yang berlaku baik norma masyarakat, adat istiadat dan agama.

\section{Perbedaan Manusia dengan Makhluk Lain}

Achmad Mubarok membedakan ciri-ciri perilaku yang membedakan dengan makhluk lainnya menjadi lima hal, yaitu; manusia memiliki kepekaan sosial, tingkah lakunya berkesinambungan, memiliki orientasi kepada tugas, memiliki sifat kejuangan dan memiliki keunikan (Mubarok, 2006:103). (1) Manusia memiliki kepekaan sosial. Kepekaan sosial artinya kemampuan untuk menyesuaikan sikap perilakunya dengan harapan dan pandangan orang lain. (2) Tingkah lakunya berkesinambungan. Apa yang dilakukan oleh manusia setiap harinya bukanlah perbuatan yang sporadic (timbul dan hilang disaat-saat tertentu), tetapi selalu ada kelangsungan atau kontinuitas. (3) Orientasi pada tugas. Setiap hari sikap perilaku manusia diorientasinya pada tugas tertentu, bukan hanya sekedar berperilaku. (4) Usaha dan perjuangan. Manusia mempunyai sikap perilaku yang menggambarkan usaha yang dipilih atau aspirasi dan nilainilai tidak sekedar hanya berperilaku. (5) Keunikan, karena pengalaman manusia berbeda-beda. Maka aspirasi, selera dan kecenderungannya juga berbeda-beda. Hal ini berakibat pada perilaku yang berbeda pula.

\section{Faktor-faktor yang Memengaruhi Perilaku Sosial}

Adapun faktor yang memengaruhi perilaku sosial adalah (1) Faktor internal. Faktor yang berasal dari dalam diri seseorang. Faktor tersebut dapat berupa insting, motif dari dalam dirinya, sikap, serta nafsu. 
Apabila dalam diri siswa tertanam nilai-nilai agama maka anak akan aktif dalam kegiatan ibadah. Begitu banyak faktor yang memengaruhi perilaku manusia. Jika faktor dalam diri anak baik maka akan menimbulkan perilaku yang baik, begitu juga sebaliknya ketika faktor dari dalam diri buruk maka akan menimbulkan perilaku yang buruk pula. Faktor internal yang bermacam-macam yang berada dalam diri seseorang akan menimbulkan bentuk perilaku sosial yang bermacam-macam. (2) Faktor eksternal. Faktor yang berasal dari luar individu. Faktor yang timbul dari keluarga, sekolah dan masyarakat akan memengaruhi perilaku sosial seorang individu pengaruh lingkungan sangat berpengaruh terhadap perilaku individu. Kondisi masyarakat yang baik akan berdampak baik pada perilaku seseorang, begitu juga perilaku masyarakat yang tidak kondusif akan menimbulkan perilaku yang buruk sebagai perwujudan dari perasaan dan emosional. Seseorang akan melakuakan apapun untuk memenuhi kebutuhannya meski dengan melakukan pelanggaran terhadap norma dan aturan yang berlaku. Selain itu aktivitas ibadah juga sangat memengaruhi perilaku sosial siswa karena dapat mengendalikan tingkah laku dalam menghadapi segala keinginan-keinginannya yang timbul. Jadi faktor yang memengaruhi sikap sosial adalah faktor intern dan faktor ekstern, melalui kerjasama yang baik antara pengalaman, penghayatan dan pengetahuan yang diajarkan, diharapkan akan terbentuk sikap keberagamaan pada diri anak dalam berinteraksi dalam keluarga maupun masyarakat nantinya. Secara normatif aktivitas ibadah haruslah dibarengi dengan perilaku seseorang agar terjadi hubungan yang erat antara kepercayaan kepada Tuhan dengan kesempurnaan perbuatan manusia sehingga manusia selalu dalam jalan yang benar, seperti dalam ayat al-Quran surat al-Baqarah ayat 82 sebagai berikut yang artinya: Dan orang-orang yang beriman serta beramal saleh, mereka itu penghuni surga; mereka kekal di dalamnya.

Secara implisit bisa dipakai bahwa dalil al-Quran sering kali kata امنوا dikaitkan dengan عملو الصلحت ini menjelaskan bahwa ada kaitan antara 
ibadah dengan perilaku sosial antara dimensi vertikal dengan dimensi horizontal. Ibadah yang dilakukan secara efektif akan melahirkan suatu perilaku yang positif. Dimana dengan keaktifan itu seseorang akan lebih berhati-hati dalam bersikap karena selalu merasakan adanya Allah. Hal itu dapat menimbulkan perilaku yang baik kepada sesamanya, tentunya ini ada kaitannya dengan perilakunya dalam interaksi sosial.

\section{Simpulan}

Aktivitas ibadah adalah kegiatan yang berupa perbuatan yang ditujukan untuk memperoleh ridha Allah. Kebiasaan-kebiasaan dan aktivitas ibadah yang ditanamkan sejak kecil sangat memengaruhi keagamaan siswa. Sebagaimana diketahui, bahwa aktivitas ibadah sangat erat hubungannya dengan perilaku sosial para siswa, dengan kesimpulan bahwa aktivitas ibadah yang tinggi maka perilaku sosial juga tinggi. Ini semua karena aktivitas ibadah menunjukkan tingkat keimanan dan ketaqwaan pada Allah sehingga tercipta manusia yang berakhlak mulia dalam kehidupan individu maupun bermasyarakat. Contohnya pada indikator mengerjakan salat wajib dan sunah. Ibadah salat jika dilakukan dengan aktif akan mampu melahirkan sikap positif yaitu menjauhi perbuatan yang keji dan mungkar. Ini ada kaitanya, apabila ibadah salat dikerjakan dengan aktif maka seseorang akan berperilaku baik dalam interaksi sosial.

Pembinaan kepribadian dapat dibentuk melalui pengaruh lingkungan, khususnya lingkungan keagamaan. Sasaran yang ditempuh atau dituju dalam pembentukan kepribadian ini adalah kepribadian yang berakhlak (berperilaku) baik. Dalam pembentukan perilaku sosial siswa, hendaknya guru menyadari bahwa dalam pembentukan perilaku sosial sangat diperlukan pembinaan-pembinaan dan latihan-latihan. Dalam hal pembentukan perilaku sosial siswa, aktivitas ibadah mempunyai peranan yang sangat penting dalam kehidupanya. Aktivitas ibadah 
berperan sebagai pengendali tingkah laku atau perbuatan yang terlahir dari sebuah keiginan yang berdasarkan emosi. Jika siswa sudah terbiasa melakukan aktivitas ibadah dalam kehidupannya sehari-hari dan sudah ditanamkannya sejak kecil, maka tingkah lakunya akan lebih terkendali dalam menghadapi segala keinginan-keinginannya yang timbul.

\section{Daftar Pustaka}

Ahmadi, Abu dan Salimi, Noor. 1994. Dasar-Dasar PAI. Jakarta: Bumi Aksara.

Arikunto, Suharsimi. 2006. Prosedur Penelitian Suatu Pendekatan Praktik. Jakarta: Asdi Mahasatya.

Daradjat, Zakiah. 1976. Pembinaan Remaja. Jakarta: Bulan Bintang. Ghazali, Imam. 2001. Ibadah Perspektif Sufistik. Surabaya: Risalah Gusti. Hadi, Sutrisno. 1982. Metode Research. Yogyakarta. Yayasan Penerbitan Fakultas Psikologi UGM.

Imarah, Mahmud Muhammad. 2008. Menari di Taman Alquran. Jakarta: Raja Grafindo Persada.

Kohlberg, Lawrence. 1995. Tahap-Tahap Perkembangan Moral. Yogyakarta: Kanisius.

Marsudi, Thomas E. 2007. Doa itu Indah, Doa itu Mudah. Yogyakarta: Gloria Graffa.

Mubarok, Achmad. 2006. Psikologi Dakwah. Jakarta: Kencana.

Musbikin, Imam. 2007. Rahasia Shalat Khusyu'. Yogyakarta: Mitra Pustaka.

Muthowi', Jasiem M. Badr. 2000. Efisiensi Waktu Konsep Islam. Surabaya, Risalah Gusti.

Poerwadarminta, W.J.S. 2002. Kamus Umum Bahasa Indonesia. Jakarta: Balai Pustaka.

--------.1982. Kamus Umum Bahasa Indonesia. Jakarta: Balai Pustaka.

-------1985. Kamus Umum Bahasa Indonesia. Jakarta: Balai Pustaka. -1995. Kamus Umum Bahasa Indonesia. Jakarta: Balai Pustaka. 
INJECT: Interdisciplinary Journal of Communication, Vol.2, No.2, Des. 2017: h. 175-192

Sugiyono. 2009. Statistik Untuk Penelitian. Bandung: Al-Fabeta.

Suyono, Moh. 1998. Fiqih Ibadah. Bandung: Pustaka Setia.

Tafsir, Ahmad. 2008. Ilmu Pendidikan dalam Perspektif Islam. Bandung: Remaja Rosdakarya Offset.

Triyanto, Agus. 2002. Ibadah dan Akhlak dalam Islam. Yogyakarta: UII Pres Indonesia.

Samsul Munir Amin. 2008. Rekonstruksi Pemikiran Dakwah Islam. Jakarta. Wahidin Saputra. 2011Pengantar Ilmu Dakwah. Jakarta.

Jum'ah Amin Abdul Aziz. 2011. Fiqih Dakwah; studi atas berbagai prinsip dan kaidah yang harus dijadikan acuan dalam dakwah islamiah. Solo. 